\title{
Comparison of thermal, structural and morphological properties of poly(L-lactide) and poly(L-lactide)/ hydroxyapatite microspheres for laser sintering processes ${ }^{*)}$
}

\author{
Anna Krokos ${ }^{1)}$, Małgorzata Gazińska),**), Bartłomiej Kryszak1), Paulina Dzienny ${ }^{2)}$,

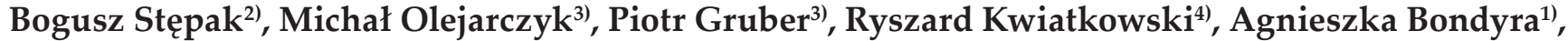 \\ Arkadiusz Antończak ${ }^{2), * *)}$
}

DOI: dx.doi.org/10.14314/polimery.2020.9.2

\begin{abstract}
A comparison of poly(L-lactide) (PLLA) and poly(L-lactide)/hydroxyapatite (PLLA/HAp) biocomposite microspheres fabricated by emulsion solvent evaporation technique designed for laser sintering (LS) applications is presented. Key properties such as thermal and structural as well as geometry, size distribution and powder flowability, which are crucial for this technique, are characterized to validate the applicability of microspheres for LS. The biocomposite microspheres turns out to be more suitable for the LS process than PLLA due to the higher thermal stability, broader sintering window and higher powder flowability.

Keywords: poly(L-lactide), hydroxyapatite, microspheres, biocomposite, laser sintering, additive manufacturing, biomedical applications, sintering window, powder flowability.

\section{Porównanie właściwości termicznych, strukturalnych oraz morfologii mikrosfer z poli(L-laktydu) i z poli(L-laktydu)/hydroksyapatytu przeznaczonych do procesu spiekania laserowego}

Streszczenie: Porównano właściwości mikrosfer z poli(L-laktydu) (PLLA) i z biokompozytu poli(L-laktyd)/hydroksyapatyt (PLLA/HAp), przygotowanych metodą emulsyjną z odparowaniem rozpuszczalnika, przeznaczonych do procesu spiekania laserowego (LS). W celu weryfikacji przydatności mikrosfer do LS scharakteryzowano kluczowe dla tej techniki właściwości: termiczne i strukturalne oraz geometrię, rozkład wymiarów i sypkość proszku. Wykazano, iż mikrosfery biokompozy towe wykazują lepsze właściwości predestynujące je do przetwarzania metodą LS niż mikrosfery PLLA, w tym większą stabilność termiczną, szersze okno parametrów spiekania i większą sypkość proszku.
\end{abstract}

Słowa kluczowe: poli(L-laktyd), hydroksyapatyt, mikrosfery, biokompozyt, spiekanie laserowe, techniki addytywne, zastosowania biomedyczne, okno spiekania, sypkość proszku.

Additive manufacturing (AM), also known as 3D printing, is a group of technologies in which manufacturing of a solid object is done by adding and bonding together thin layers of material in a layer-by-layer manner. One of AM's principal technologies is a versatile process called laser sintering which is applicable to systems based on powder materials $[1,2]$.

Laser sintering is a powder bed fusion (PBF) technology, which uses laser as a heat source to fuse (melt or sinter) polymeric material in the form of powder. The

\footnotetext{
1) Wroclaw University of Science and Technology, Faculty of Chemistry, Polymer Engineering and Technology Division, C.K. Norwida 4/6, 50-373 Wrocław, Poland.

2) Wroclaw University of Science and Technology, Faculty of Electronics, Laser and Fibre Electronics Group, Wybrzeże Wyspiańskiego 27, 50-370 Wrocław, Poland.

3) Wroclaw University of Science and Technology, Faculty of Mechanical Engineering/Centre of Advanced Manufacturing Technologies - Fraunhofer Project Center (CAMT-FPC), Łukasiewicza 5, 50-371 Wrocław, Poland.

4) University of Bielsko-Biała, Institute of Textile Engineering and Polymer Materials, Willowa 2, 43-309 Bielsko-Biała, Poland.

*) Material contained in this article was presented at the XI International Conference on "X-ray Investigations of Polymer Structure", 3-6 December 2019, Ustroń, Poland.

**) Authors for correspondence: malgorzata.gazinska@pwr.edu.pl, arkadiusz.antonczak@pwr.edu.pl
} 
LS process starts with preheating of the powder material, then a laser whose wavelength is within the optical absorption range of the material being processed, mostly $\mathrm{CO}_{2}$, is used to scan the desired cross-section, fusing a layer of powder particles together, after which the building platform is lowered and another layer of powder is applied and the process is repeated layer by layer. The unfused powder acts as a support, so additional support structures are not required [3].

Nowadays, additive manufacturing is a novel approach to produce medical devices in the regenerative medicine sector [1]. Materials intended for medical applications should be biocompatible and - in the case when their role is limited to only a specific period after which they are no longer needed - bioresorbable. Osteoconductivity and osteoinductivity, which positively affect the processes of osteogenesis, are two important features of the materials used to rebuild bone defects. For this purpose, biopolymers are often doped with an intercellular substance hydroxyapatite (HAp).

The poly(L-lactide)/hydroxyapatite (PLLA/HAp) biocomposites are biomaterials designed for tissue engineering. PLLA is bioresorbable; during the degradation process, it hydrolyses into relatively harmless and well metabolized side products. However, PLLA is not osteoconductive, so cannot be replaced by bone cells during its resorption. Because of osteoconductivity and the similarity to natural bones, incorporation of the bioactive HAp particles into the PLLA matrix could improve the reconstruction of a bone defect. Compared to PLLA, the advantage of using the PLLA/HAp biocomposites is that after their implementation HAp will support the biomineralization process [4,5]. Moreover, it has been proved that even a small addition of HAp significantly improves the biological response of bone cells, their adhesion, proliferation and cytocompatibility [6, 7].

Very few research teams around the world have studied the subject of PLLA/HAp composite microspheres for biomedical applications [8-13]. Some of them suggested using them as injectable bone substitutes [10], others as substrates for bone scaffolds using the hot pressing method [9]. Wen You Zhou [8] investigated such microspherical powders as a substitute for laser sintering. Several methods are used to produce the PLA/HAp microspheres, e.g. the solid-in-oil-in-water $(\mathrm{S} / \mathrm{O} / \mathrm{W})$ emulsion solvent evaporation method $[8,9,12,13]$ and the modified $(\mathrm{S} / \mathrm{O} / \mathrm{W})$ method combined with HAp precipitation [10, 11]. Various modifications of the preparation method lead to obtaining microspheres of various size (from several dozen [9] to several hundred micrometers [13]), various porosity, etc. However, despite many literature reports, the aspect of thermal analysis of the PLA/HAp microspherical powders has not been studied so far. It should be mentioned that such investigations are necessary in the context of further applications in laser sintering.

Correct LS process is conditioned by the following factors: the linking mechanism associated with the thermal phenomena, the material with its characteristics and the system operation along with the manufacturing parameters. In our work the emphasis was put on the characterization of material. The material used in the LS process should be characterized by given thermal and optical properties as well as its morphology (particle size and shape), which mainly determine its processability [14]. The shape and surface of a single particle of material are among the most important factors that affect the powder behavior in the LS process. The most desirable powder shape is that resembling a sphere, which guarantees the free flow of the powder in a feeding system [15]. Powder flowability is important because of the method of applying it in the process, e.g. by a moving recoater (blade) or roller, so it has to be loose enough and should not show a tendency to caking. Moreover, the density of the processed material directly depends on that of applied powder layer. The particle shape discussed depends on the method of its preparation. The following can be distinguished: spherical, potato-shaped (particle with a reduced roundness) and edged (powder with angular surface).

The main goal of this research was to characterize selected parameters (mean particle size and size distribution, shape, residual solvent content, thermal stability, processing window and powder flowability) that are crucial in LS and in verifying the suitability of the PLLA and PLLA/HAp microspheres for this technology. The impact of hydroxyapatite particles on the above mentioned properties of PLLA is also determined.

\section{EXPERIMENTAL PART}

\section{Materials}

In our research medical grade poly(L-lactide) Resomer L207S (inherent viscosity 1.5-2.0 dL/g) supplied by Evonik was used. Hydroxyapatite nanopowder (HAp) with particle size $<200 \mathrm{~nm}$ and poly(vinyl alcohol) (PVA, Mowiol 18-88, $M_{w} \sim 130000,86-89 \%$ hydrolyzed) were purchased from Sigma Aldrich. Dichloromethane (DCM) 99.5\% from Stanlab was used as a solvent. Hydroxyapatite was dried at $110^{\circ} \mathrm{C}$ for $25 \mathrm{~h}$ in a vacuum drier before use, other materials were used as received.

\section{Fabrication of microspheres}

Composite microspheres made of PLLA with a $10 \mathrm{wt} \%$ content of HAp were prepared by the solid-in-oil-in-water emulsification $(\mathrm{S} / \mathrm{O} / \mathrm{W})$. The dispersion of HAp in $10 \mathrm{~cm}^{3}$ of DCM was sonicated for 10 min and added to a $4 \% \mathrm{w} / \mathrm{v}$ solution of PLLA in DCM. The solid-in-oil (S/O) dispersion was mixed for $10 \mathrm{~min}$ with a magnetic stirrer and emulsified in the aqueous PVA solution $(1 \% \mathrm{w} / \mathrm{v})$ by dropwise addition with a peristaltic pomp into the PVA solution stirred at $800 \mathrm{rpm}$. The PLLA microspheres were prepared using the oil-in-water technique $(\mathrm{O} / \mathrm{W})$. 
The PLLA solution in DCM was emulsified into the aqueous PVA phase just as the composite microspheres. The volume ratio of the organic phase to the aqueous phase was $1: 3$. The stirring of composite microspheres was carried out for $48 \mathrm{~h}$ at room temperature to allow the dichloromethane to evaporate. Finally, the composite microspheres were separated by centrifuging and were dried in vacuum at $40^{\circ} \mathrm{C}$ for $24 \mathrm{~h}[9,16]$.

\section{Methods of testing}

- Thermogravimetry (TGA) measurements were performed using the TGA/DSC1 Mettler Toledo system. Samples were heated from $25^{\circ} \mathrm{C}$ to $650^{\circ} \mathrm{C}$ at a rate of $10 \mathrm{deg} / \mathrm{min}$ under $60 \mathrm{~cm}^{3} / \mathrm{min}$ of nitrogen flow.

- Differential scanning calorimetry (DSC) measurements were performed using a Mettler Toledo DSC1 system, coupled with a Huber TC 100 intracooler. The instrument was calibrated using indium $\left(T_{m}=156.6^{\circ} \mathrm{C}, \Delta H_{m}=28.45 \mathrm{~J} / \mathrm{g}\right)$ and zinc $\left(T_{m}=419.7^{\circ} \mathrm{C}\right.$, $\left.\Delta H_{m}=107.00 \mathrm{~J} / \mathrm{g}\right)$ standards. Samples $(\sim 3.5 \mathrm{mg})$ were measured in $0.04 \mathrm{~cm}^{3}$ aluminum pans under a constant nitrogen purge $\left(60 \mathrm{~cm}^{3} / \mathrm{min}\right)$ from $0^{\circ} \mathrm{C}$ to $200^{\circ} \mathrm{C}$. The heating and cooling rate were set to $5^{\circ} \mathrm{C} / \mathrm{min}$. The initial degree of crystallinity of PLLA was calculated from the first heating DSC curve according to Equation (1):

$$
X_{c}=\frac{\Delta H_{m}}{\Delta H_{m}^{100 \%}}
$$

where: $\Delta H_{m}$ - melting enthalpy of PLLA [J/g], $\Delta H_{m}^{100 \%}-$ melting enthalpy of $\alpha$-crystals of $100 \%$ crystalline PLLA, $143 \mathrm{~J} / \mathrm{g}$ [17].

- Wide-angle X-ray diffraction (WAXD) experiments were done at room temperature on a Rigaku Ultima IV diffractometer (Bragg-Brentano geometry). Measurements were carried out using an X-ray tube with a copper anode $\mathrm{CuK} \alpha(\lambda=1.54178 \AA)$, powered by a high voltage generator $(40 \mathrm{kV}, 30 \mathrm{~mA})$. Data were collected within the range of $2 \theta$ from 2.5 to $60.0^{\circ}$ in a fixed time-scan mode with a step width of $0.005^{\circ}$ and the speed of $5 \% \mathrm{~min}$. The background corrected WAXD patterns were resolved into Lorentzian shape diffraction peaks and diffusion maxima by using the Levenberg-Marquardt non-linear fitting procedure implemented in OriginPro 9.0. The curve fitting coefficient $r^{2}$ was approximately $99.9 \%$. The deconvolution of the diffraction curve of composite microspheres was carried out based on available literature on the crystalline structure of PLLA and HAp [18-21].

- A scanning electron microscope (Zeiss SEM EVO MA25) was used to determine the morphology of prepared powder. To ensure a high resolution of analysis, the samples were coated with $\mathrm{Au}$ (sputter current: $40 \mathrm{~mA}$, sputter time: 50 s) using a Quorum machine. Captured images were used to qualify powder morphology such as particle shape, size and surface, which influence powder flowability that is one of the key factors for LS powder preparation [15].
- Dry laser diffraction spectroscopy (HELOS/BR 4470C, RODOS/T4, R4) was used to measure the powder particle size and distribution. To ensure proper optical concentration, the samples were fed with a VIBRI feeder (with the feed rate of $80 \%$ and the gap width at $3.5 \mathrm{~mm}$ ) and dispersed using a pressure of $0.2 \mathrm{MPa}$. Along with the cumulative distribution and distribution density, the particle size, D50, was determined that represents the powder particle diameter. In terms of volume, $50 \%$ of the powder consists of smaller particles, including those below $20 \mu \mathrm{m}$, which adversely affect the powder flowability, especially at high temperatures [14].

- The dynamic powder flowability was evaluated using the Revolution Powder Analysis (RPA). Measurements were carried out using the GranuDrum (GranuTools) with a drum with an inner diameter of $84 \mathrm{~mm}$ and $20 \mathrm{~mm}$ in width. For each batch the drum was filled with $55 \mathrm{~cm}^{3}$ of powder. The sampling time was set to 1 second with frame count 25 for each tested rotational speed. The basic dynamic flowability parameters such as the first avalanche angle (AA), flowing angle $\left(\alpha_{\mathrm{f}}\right)$ and cohesive index $\left(\sigma_{\mathrm{f}}\right)$ were calculated with respect to the rotational speed (2 and $60 \mathrm{rpm}$ ).

\section{RESULTS AND DISCUSSION}

\section{Scanning electron microscopy}

SEM images for both analyzed materials are shown in Fig. 1.

The particles of PLLA can be distinguished as a spherical shape with a smooth and homogenous surface, which is commonly referred to as powder morphology favorable for the LS process [15]. In Figs. 1c, 1d the biocomposite microspheres with visible inclusions of HAp are shown. Compared to neat PLLA, the microspheres prepared with added HAp have reduced sphericity and surface smoothness. Moreover, some particle pores are visible, which yields an overall less desirable but still suitable powder's morphology for LS.

\section{Thermogravimetry}

A thermogravimetric analysis shown in Fig. 2 was carried out for composite microspheres in order to determine

$\mathrm{T}$ a b l e 1. Mass losses at $200^{\circ} \mathrm{C}$ and $600^{\circ} \mathrm{C}$ and the temperature corresponding to $5 \mathrm{wt} \%$ of mass loss of hydroxyapatite particles and microspheres of PLLA and PLLA/HAp

\begin{tabular}{c|c|c|c}
\hline Material & $\begin{array}{c}\text { Mass loss at } \\
25-200^{\circ} \mathrm{C} \\
\%\end{array}$ & $\begin{array}{c}\text { Mass loss at } \\
25-600^{\circ} \mathrm{C} \\
\%\end{array}$ & $\begin{array}{c}T_{-5 \%} \\
{ }^{\circ} \mathrm{C}\end{array}$ \\
\hline PLLA & 0.0008 & 99.0251 & 330.7 \\
PLLA/HAp & 0.1310 & 91.8339 & 336.2 \\
HAp & 0.4259 & 0.7599 & - \\
\hline
\end{tabular}


a)

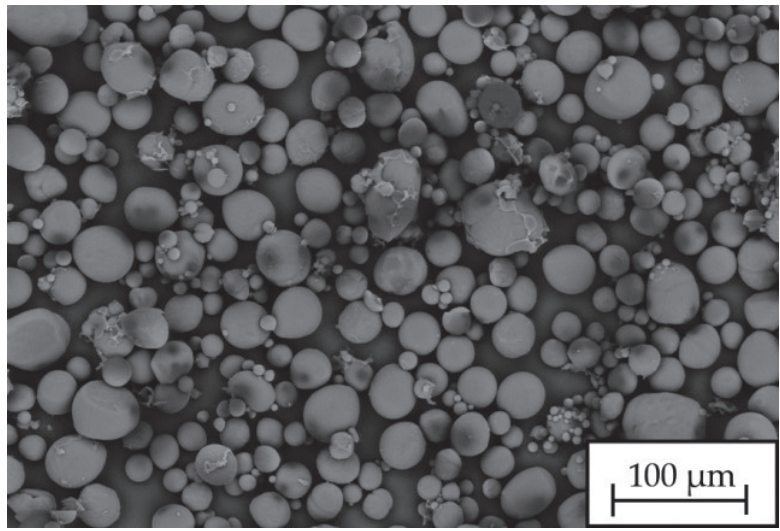

c)

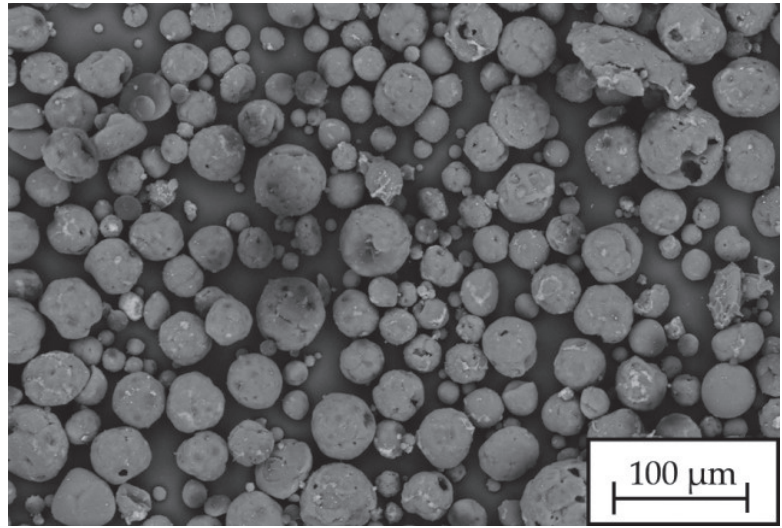

b)

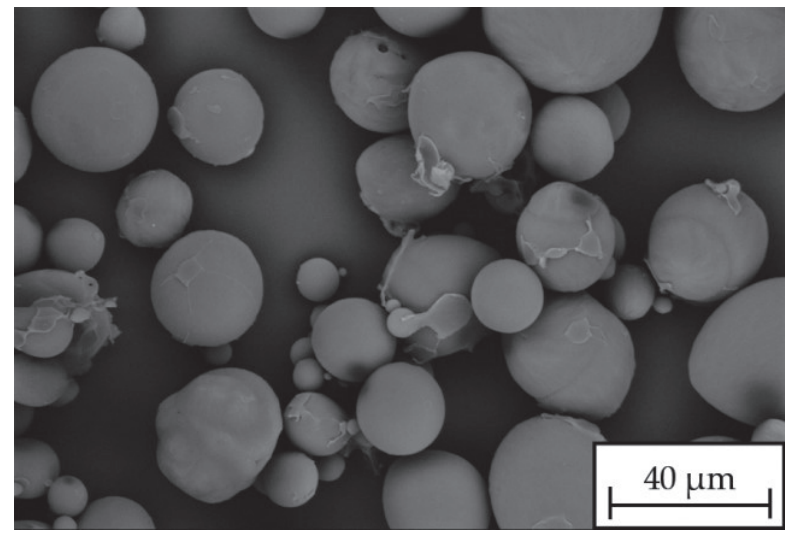

d)

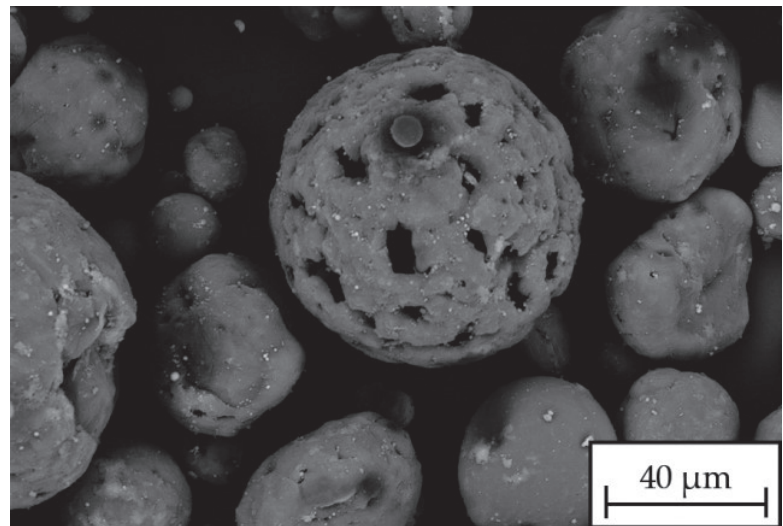

Fig. 1. SEM images of: a, b) PLLA, c, d) PLLA/HAp

the thermal stability of microspheres and the hydroxyapatite and residual solvent content.

Mass losses at $200^{\circ} \mathrm{C}$ and $600^{\circ} \mathrm{C}$ and the temperature corresponding to $5 \mathrm{wt} \%$ of mass loss $\left(T_{-5 \%}\right)$ of hydroxyapatite particles and microspheres of PLLA and PLLA/HAp are summarized in Table 1.

TGA confirms the presence of HAp particles in microspheres, as indicated by the 8.17 wt \% residue at $600^{\circ} \mathrm{C}$ whereas the PLLA microspheres are almost completely degraded. Precise HAp content in composite microspheres was calculated from mass loss at $600^{\circ} \mathrm{C}$, taking into account

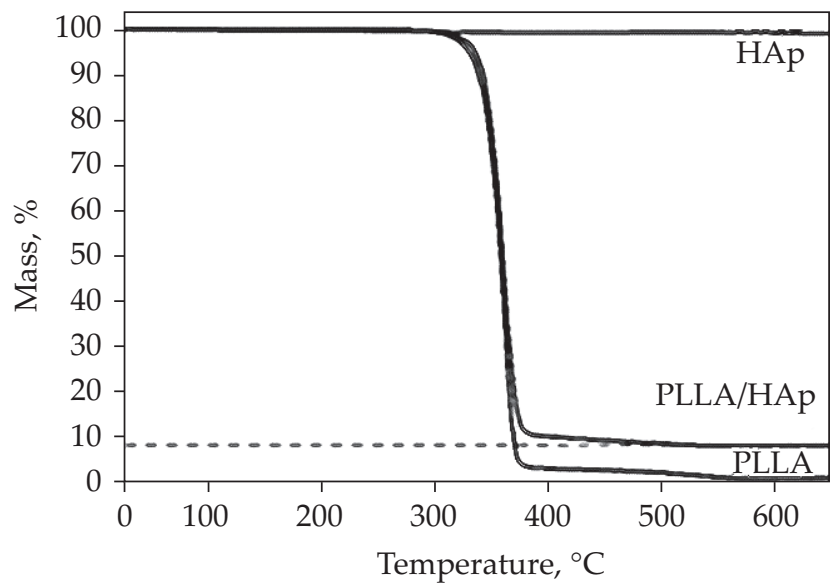

Fig. 2. TGA curves of HAp particles and the microspheres of PLLA and PLLA/HAp a mass loss of $0.76 \mathrm{wt} \%$ of neat HAp. The established HAp content of $7.32 \mathrm{wt} \%$ is lower than assumed in the microsphere preparation procedure. Moreover, to investigate the influence of HAp on the thermal stability of microspheres, the temperature corresponding to the $5 \mathrm{wt} \%$ of mass loss $\left(T_{-5 \%}\right)$ was determined. $T_{-5 \%}$ value for composite microspheres is $5.5^{\circ} \mathrm{C}$ higher than that for the microspheres of neat PLLA. Residual solvents and adsorbed/absorbed water content are important in additive processing as a key quality parameter of applied powders. In order to minimize the aggregation of powder particles and to avoid the formation of explosive vapors during laser treatment, the residual solvents must be removed [15]. The residual solvent content determined as a mass loss at $200^{\circ} \mathrm{C}$ for thus prepared composite microspheres was $0.13 \mathrm{wt} \%$, which indicates that an additional drying step is required. Detailed analysis of the conditioning parameters such as the drying temperature and time on the thermal and structural properties of microspheres will be discussed in our next paper.

\section{Differential scanning calorimetry}

The DSC analysis was performed in order to characterise the thermal properties of microspheres, such as the glass transition temperature $\left(T_{q}\right)$, melting temperature $\left(T_{m}\right)$, crystallization temperature $\left(T_{c}\right)$ and enthalpy of melting $\left(\Delta H_{m}\right)$ and crystallization $\left(\Delta H_{c}\right)$ and the influence of HAp on the thermal properties of PLLA. The main 
$\mathrm{T}$ a b 1 e 2. The thermal parameters of the PLLA and PLLA/HAp microspheres based on the first and second heating DSC scans

\begin{tabular}{|c|c|c|c|c|c|c|c|c|c|c|}
\hline Microspheres & $T_{g^{\prime}}{ }^{\circ} \mathrm{C}$ & $T_{c c}{ }^{\text {onset }},{ }^{\circ} \mathrm{C}$ & $T_{c c^{\prime}}{ }^{\circ} \mathrm{C}$ & $\Delta H_{c c^{\prime}} \mathrm{J} / \mathrm{g}$ & $\Delta H_{\alpha^{\prime}-\alpha^{\prime}} \mathrm{J} / \mathrm{g}$ & $T_{m}{ }^{b},{ }^{\circ} \mathrm{C}$ & $T_{m}{ }^{\text {onset }},{ }^{\circ} \mathrm{C}$ & $T_{m}{ }^{\text {peak }},{ }^{\circ} \mathrm{C}$ & $\Delta H_{m^{\prime}} \mathrm{J} / \mathrm{g}$ & $X_{c}^{\mathrm{DSC}}, \%$ \\
\hline \multicolumn{11}{|c|}{$1^{\text {st }}$ heating } \\
\hline PLLA & 75.3 & - & - & - & - & 135.1 & 174.9 & 178.4 & 59.07 & 41.3 \\
\hline PLLA/HAp & 70.1 & - & - & - & - & 145.5 & 174.2 & 178.2 & 52.13 & 39.3 \\
\hline \multicolumn{11}{|c|}{$2^{\text {nd }}$ heating } \\
\hline PLLA & 61.3 & 86.4 & 99.5 & -5.43 & -6.15 & - & - & 177.9 & 48.42 & 33.9 \\
\hline PLLA/HAp & 65.3 & 97.2 & 98.2 & -1.51 & -1.60 & - & - & 179.2 & 44.76 & 34.8 \\
\hline
\end{tabular}

$\mathrm{T}$ a b 1 e 3. The thermal parameters of the PLLA and PLLA/HAp microspheres based the cooling DSC scan

\begin{tabular}{c|c|c|c|c|c|c}
\hline Microspheres & $T_{c}{ }^{\text {onset, }},{ }^{\circ} \mathrm{C}$ & $T_{c^{\prime}}{ }^{\circ} \mathrm{C}$ & $\Delta H_{c^{\prime}} \mathrm{J} / \mathrm{g}$ & $T_{g^{\prime}}{ }^{\circ} \mathrm{C}$ & $\mathrm{SW}_{\text {beginning }^{\prime}}{ }^{\circ} \mathrm{C}$ & $\mathrm{SW}_{\text {onset }^{\prime}}{ }^{\circ} \mathrm{C}$ \\
\hline PLLA & 116.1 & 106.4 & -28.87 & 61.5 & $116.1-135.1$ & $116.1-174.9$ \\
PLLA/HAp & 120.4 & 112.9 & -34.30 & 68.0 & $120.4-145.1$ & $120.4-174.2$ \\
\hline
\end{tabular}

purpose was to determine the temperature range of the processing window.

In Fig. 3 the DSC curves of the PLLA and PLLA/HAp microspheres are shown and the determined thermal properties are collected in Tables 2 and 3. In the DSC curves from the first heating there are two characteristic thermal effects: the glass transition with $T_{g}$ at $75.3^{\circ} \mathrm{C}$ for PLLA and at $70.1^{\circ} \mathrm{C}$ for the PLLA/HAp microspheres and the melting endotherm with a peak temperature $\left(T_{m}\right)$ at $178^{\circ} \mathrm{C}$. The glass transition temperature of the PLLA microspheres determined from the first heating is higher than that of PLLA in composite microspheres. This is mainly due to the higher crystallinity of PLLA. Typically, an opposite influence of HAp particles on $T_{g}$ of PLLA is observed [22]. The higher $T_{g}$ of PLLA in the presence of HAp is explained by the reduced chain segment mobility in the amorphous phase. In the case of presented microspheres we can suggest that the higher $T_{g}$ of PLLA is mainly due to the higher crystallinity. This interpretation agrees with the results on $T_{g}$ for both cooling and the second heating. In contrast to the first heating, $T_{g}$ for PLLA in composite microspheres is higher than that for PLLA microspheres, as determined in cooling

a)

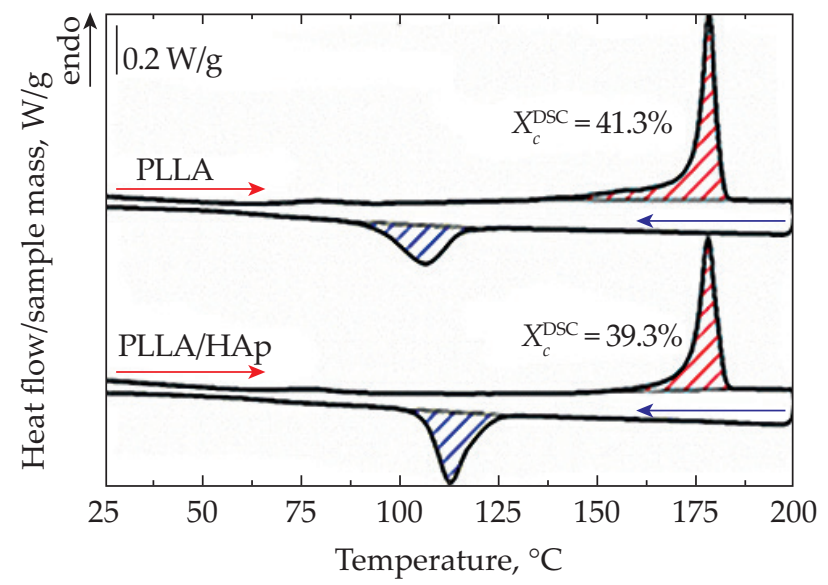

and the second heating. The difference in $T_{g}$ of the PLLA and PLLA/HAp microspheres could be explained by the well-known influence of morphology on the $T_{g}$ properties of PLLA [23].

Another difference between the PLLA and PLLA/HAp microspheres, important in terms of LS, concerns the temperature range of melting transition. The PLLA microspheres are characterized by a broader range of melting than those made of PLLA/HAp. Beginning of melting endotherm $\left(T_{m}^{b}\right)$ of PLLA begins at $135.1^{\circ} \mathrm{C}$, whereas $T_{m}^{b}$ of PLLA in composite microspheres is $10^{\circ} \mathrm{C}$ higher. The higher initial temperature of melting of composite microspheres is beneficial to the sintering window. The sintering window for semicrystalline polymers is typically defined as the temperature band between the onset of melting and that of melt crystallization [15]. The sintering window defined in this way $\left(S W_{\text {onset }}\right)$ is within the range of $116.1-174.9^{\circ} \mathrm{C}$ for the PLLA microspheres and $120.4-174.2^{\circ} \mathrm{C}$ for the composite microspheres. We suggest to use temperature of beginning of melting endotherm $\left(T_{m}^{b}\right)$ instead of the onset temperature. The melting of the semicrystalline polymers is a very broad transition and the onset temperature doesn't take into account b)

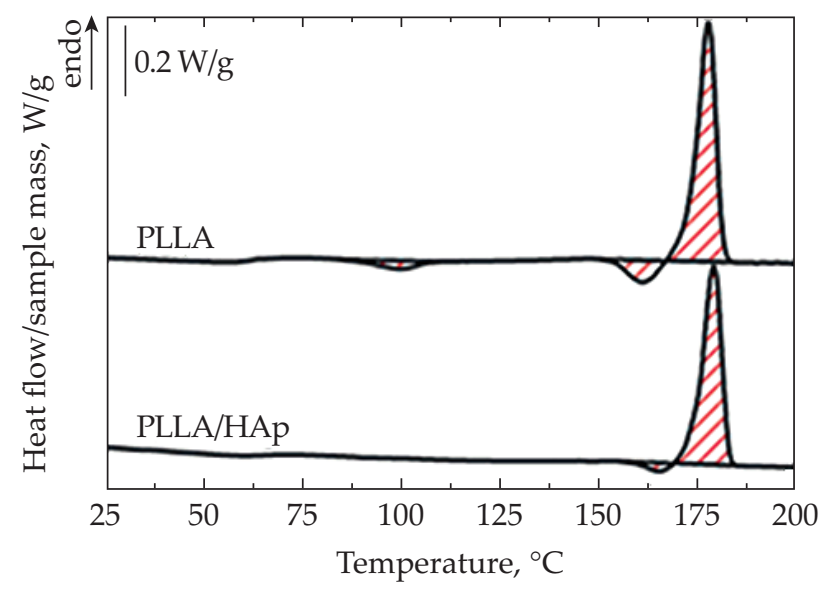

Fig. 3. DSC curves of the PLLA and PLLA/HAp microspheres: a) the first heating and cooling, b) the second heating 
the shape of the leading edge of polymer melting peak. Thus, we designate the beginning of melting endotherm $\left(T_{m}{ }^{b}\right)$ as a high temperature limit of the sintering window $\left(\mathrm{SW}_{\text {beginning }}\right)$. The higher temperature limit of the sintering window set at $T_{m}^{b}$ allows one to consider the existence of a broad leading edge of the melting peak such as in the case of the PLLA microspheres and eliminates from the sintering window any thermal phenomena occurring above $T_{m}^{b}$. SW $W_{\text {beginning }}$ is narrower than $S W_{\text {onset }}$ and respects the range of $116.1-135.1^{\circ} \mathrm{C}$ for the PLLA microspheres and $120.4-145.1^{\circ} \mathrm{C}$ for the composite microspheres. Compared to the PLLA microspheres, the composite microspheres have a broader processing window, set as the temperature range between $T_{c}^{\text {onset }}$ and the beginning of melting endotherm, despite the higher onset temperature of melt crystallization.

The narrower range of melting transition for the PLLA/HAp microspheres is also associated with the lower melting enthalpy of PLLA in composite microspheres compared to the neat PLLA microspheres. Thus, PLLA in composite microspheres has a lower crystallinity $\left(X_{c}{ }^{\mathrm{DSC}}\right)$, as calculated taking into account the enthalpy of melting of $\alpha$-form $100 \%$ crystalline PLLA $\left(\Delta H_{m}{ }^{100 \%}\right)$ [17]. The presence of only $\alpha$-form crystals is indicated by there being no exothermic effect of $\alpha^{\prime}-\alpha$ transition in the first heating DSC curves [24]. The lower $X_{c}^{\text {DSC }}$ of PLLA in the composite indicates that the HAp particles do not increase the crystallinity of PLLA during microsphere formation. But as evidenced by the higher onset temperature $\left(T_{c}^{\text {onset }}\right)$ and the peak temperature $\left(T_{c}{ }^{\text {peak }}\right)$ of melt crystallization exotherm, the higher enthalpy $\left(\Delta H_{c}\right)$ and the narrower temperature range, the HAp particles nucleate melt crystallization of PLLA. On subsequent heating both types of microspheres crystallize above the glass transition, but the enthalpy of cold crystallization $\left(\Delta H_{c c}\right)$ of composite microspheres if lower than that of PLLA microspheres. The next difference in thermal properties is concerned with the $\alpha^{\prime}-\alpha$ transition, as it stems from

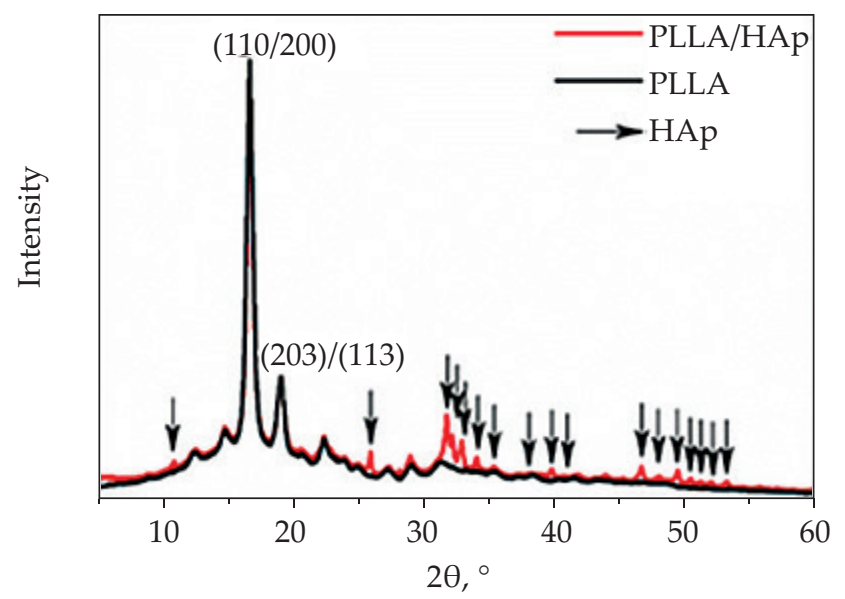

Fig. 4. Diffraction curves of the PLLA and PLLA/HAp microspheres the shape of the small exothermic peak preceding the melting of PLLA noticeable in the second heating DSC curves. The enthalpy of $\alpha^{\prime}-\alpha$ transition $\left(\Delta H_{\alpha^{\prime}-\alpha}\right)$ in composite microspheres is lower due to the lower enthalpy of cold crystallization upon $\alpha^{\prime}$ phase was formed.

\section{Wide-angle X-ray diffraction analysis}

The WAXD analysis was carried out to confirm the composite structure of the produced microspheres and to determine the degree of crystallinity of the polymer in the composite microspheres. Figure 4 shows the diffraction patterns obtained for the PLLA/HAp microspheres (the red line) in relation to those obtained for the neat PLLA microspheres (the black line). The course of the reference curve is characteristic of polylactide $[19,21]$.

The diffraction maxima on the graph denoted with stars correspond to the crystalline $\alpha$ phase of this polymer. Additional reflections (marked with an arrow) can be seen for the PLLA/HAp sample (especially for angular positions above 25 degrees) that correspond to the HAp crystal structure [18]. The obtained diffraction curves were deconvoluted into the diffraction peaks derived from the crystal structure of PLLA and HAp and the diffuse scattering maxima indicating the presence of the amorphous phase of PLLA. Deconvolution for the PLLA/HAp microspheres is shown in Fig. 5.

The deconvolution for neat PLLA was carried out according to the same procedure. The crystallinity degree $\left(X_{c}^{\text {WAXD }}\right)$ of PLLA was calculated as a ratio of integral intensities of PLLA crystalline reflections to the total integral intensity (excluding the reflections assigned to hydroxyapatite). This ratio was $41.9 \%$ for PLLA in the composite microspheres and $45.1 \%$ for the neat PLLA microspheres. These results agree with the calorimetric analysis. A lower crystallinity of PLLA in composite microspheres was also calculated based on the DSC results. Based on integral intensities attributed to HAp, the content of HAp crystal

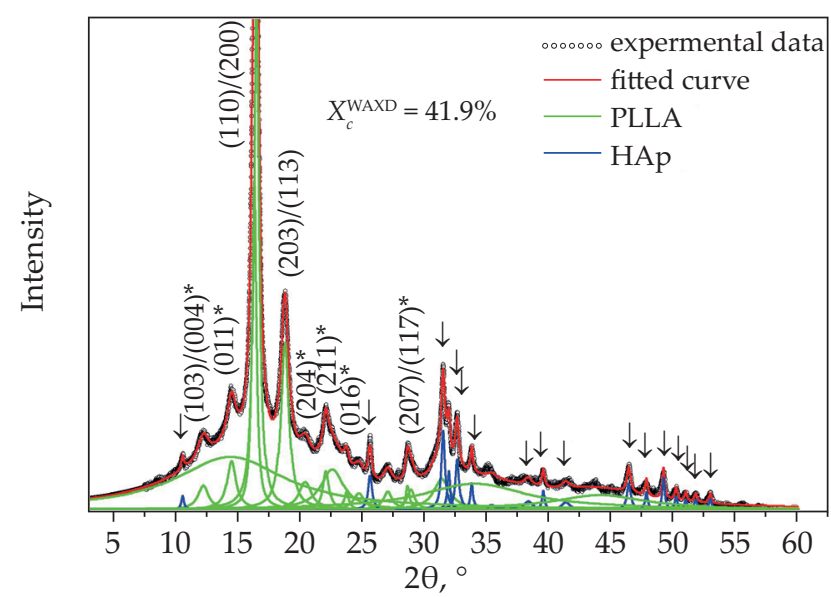

Fig. 5. Deconvolution of the diffraction profile for the PLLA/HAp microspheres 


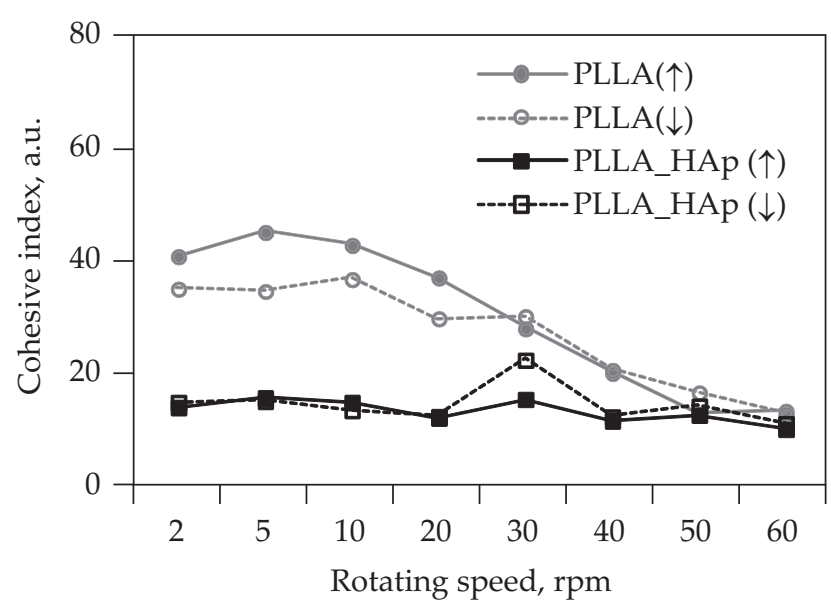

Fig. 6. Cumulative distribution and distribution density of the PLLA and PLLA/HAp powders

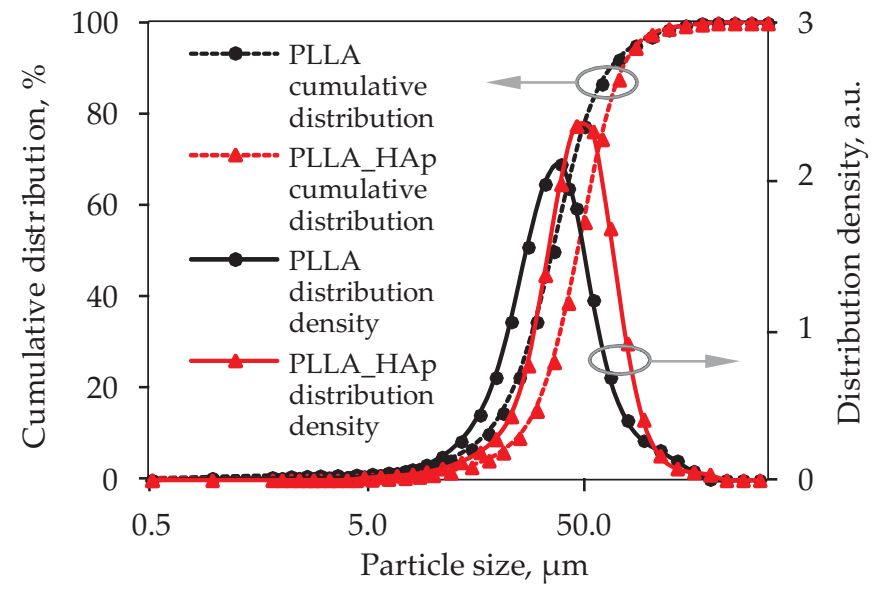

Fig. 7. Cohesive index curves recorded as a function of the increasing $(\uparrow)$ and decreasing $(\downarrow)$ rotation speed for the prepared powders

T a b l e 4 . The first avalanche angle (AA), flowing angle $\left(\alpha_{\mathrm{f}}\right)$, cohesive index $\left(\sigma_{\mathrm{f}}\right)$ and particle size distribution of prepared powders

\begin{tabular}{|c|c|c|c|c|c|}
\hline \multirow{2}{*}{ Microspheres } & \multirow{2}{*}{$\mathrm{AA},{ }^{\circ}$} & $\alpha_{\mathrm{f}^{\prime}}{ }^{\circ}$ & $\sigma_{f}$, a.u. & \multirow{2}{*}{$\mathrm{d} 50, \mu \mathrm{m}$} & \multirow{2}{*}{$<20 \mu \mathrm{m}, \%$} \\
\hline & & \multicolumn{2}{|c|}{ at $30 \mathrm{rpm}$ (increasing speed) } & & \\
\hline PLLA & 30.0 & 51.0 & 28.0 & 36.01 & 14.60 \\
\hline PLLA/HAp & 38.3 & 36.2 & 15.4 & 47.08 & 6.02 \\
\hline
\end{tabular}

domains was determined to be $6.3 \%$, which is in good relation to the HAp content derived from the TGA curve.

\section{Particle size distribution}

The cumulative distribution and the distribution density of the prepared microspheres are shown in Fig. 6.

Both powder distributions can be characterized as normal, narrow and unimodal. Basic PSD (Particle Size Distribution) parameters are listed in Table 4.

The microspheres with added HAp are bigger and have less particles below $10 \mu \mathrm{m}$, which in this case should be beneficial in terms of powder flowability properties. The powder distribution for both PLLA and PLLA/HAp meets the requirements stated for the raw material for LS.

\section{Powder flowability}

The basic flowability parameters are shown in Table 4. Cohesion index curves are presented in Fig. 7.

The avalanche angle, which is the first angle that triggers the pouring of powder, provides information that in the quasi-static conditions raw PLLA has a better flowability. However, when looking at the cohesive index, especially for lower velocities (up to $40 \mathrm{rpm}$ ) one can see that the dynamic flowability properties of PLLA/HAp are significantly better, which shows by the smaller cohesive index. These differences may be caused by the lower percentage of particles below $10 \mu \mathrm{m}$ and the overall bigger size of particles in the composite PLLA powder.

\section{CONCLUSIONS}

The PLLA microspheres and the PLLA/HAp biocomposite microspheres were obtained using the traditional emulsion solvent evaporation method. The materials that we received have a spherical shape with the median diameter of $36 \mu \mathrm{m}$ and $47 \mu \mathrm{m}$ for the PLLA and the PLLA/HAp microspheres, respectively. An addition of $c a .10 \mathrm{wt} \%$ of hydroxyapatite to the PLLA matrix resulted in remarkably better dynamic flowability properties (15.4 a.u.) compared to the case of neat PLLA microspheres (28.0 a.u.). Hydroxyapatite also has improved the thermal stability of biocomposite $\left(330.7^{\circ} \mathrm{C}\right.$ for PLLA compared to $336.2^{\circ} \mathrm{C}$ for PLLA/HAp). The sintering window, i.e. the range between the temperature of the beginning of melting endotherm and that of the onset of melt crystallization is $30 \%$ broader for the PLLA/HAp microspheres compared to than for the neat PLLA microspheres. Detailed characteristics of the PLLA and PLLA/HAp microspheres indicate suitability of both these types of materials for the laser sintering process, although the PLLA/HAp microspheres have better properties. Both materials were prepared for testing using a new two-beam laser sintering 
method, in which one beam preheats the material in a larger area, while the second one, with a small diameter, sinters the microsphere with a given resolution. This research will be presented in our next publication.

\section{ACKNOWLEDGMENTS}

This work was supported by the National Center of Science (NCN) under Grant No. UMO-2017/27/B/ST8/01780 and by project OPUS "Laser modification of bioresorbable polymeric materials in thermal additive processes".

\section{REFERENCES}

[1] Gibson I., Srinath A.: Procedia Technology 2015, 20, 237. https://doi.org/10.1016/j.protcy.2015.07.038

[2] Shirazi S.F.S., Gharehkhani S., Mehrali M. et al.: Science and Technology of Advanced Materials 2015, 16, 1. https://doi.org/10.1088/1468-6996/16/3/033502

[3] Szymczyk P., Labowska M.B., Detyna J. et al.: Biocybernetics and Biomedical Engineering 2020, 426, 1. https://doi.org/10.1016/j.bbe.2020.01.015

[4] Hunt J.A., Callaghan J.T.: Knee Surgery, Sports Traumatology, Arthroscopy 2008, 16, 655. https://doi.org/10.1007/s00167-008-0528-8

[5] Ignjatovic N., Uskokovic D.: Applied Surface Science 2004, 238, 314. https://doi.org/10.1016/j.apsusc.2004.05.227

[6] Szustakiewicz K., Gazińska M., Kryszak B. et al.: European Polymer Journal 2019, 113, 313. https://doi.org/10.1016/j.eurpolymj.2019.01.073

[7] Smieszek A., Marycz K., Szustakiewicz K. et al.: Materials Science and Engineering: C 2019, 98, 213. https://doi.org/10.1016/j.msec.2018.12.099

[8] You W., Wang M., Lam W. et al.: "Tissue Engineering" (Ed. Eberli D.), IntechOpen, Zurich 2010, pp. 179-204.

[9] Russias J., Saiz E., Nalla R.K. et al.: Journal of Materials Science 2006, 41, 5127. https://doi.org/10.1007/s10853-006-0449-1

[10] Nagata F., Miyajima T., Teraoka K. et al.: Key Engineering Materials 2005, 284-286, 819. https://doi.org/10.4028/www.scientific.net/kem.284286.819

[11] Nagata F., Miyajima T., Yokogawa Y.: Journal of the European Ceramic Society 2006, 26, 533. https://doi.org/10.1016/j.jeurceramsoc.2005.06.006

[12] Nagata F., Miyajima T., Yokogawa Y.: Chemistry Letters 2003, 32, 784.

https://doi.org/10.1246/cl.2003.784

[13] He S., Lin K.F., Sun Z. et al.: Artificial Organs 2016, 40, 128. https://doi.org/10.1111/aor.12741

[14] Schmid M., Amado A., Wegener K.: AIP Conference Proceedings 2015, 1664, 160009. https://doi.org/10.1063/1.4918516

[15] Schmid M.: "Laser Sintering with Plastics: Technology, Processess and Materials" (Ed. Verlag C.H.), Carl Hanser Verlag GmbH \& Co. KG, 2018, pp. 1-217.

[16] Ryu T.K., Kim S.E., Kim J.H. et al.: Journal of Bioactive and Compatible Polymers 2014, 29, 445. https://doi.org/10.1177/0883911514544011

[17] Righetti M.C., Gazzano M., Di Lorenzo M.L. et al.: European Polymer Journal 2015, 70, 215. https://doi.org/10.1016/j.eurpolymj.2015.07.024

[18] Kryszak B., Szustakiewicz K., Stępak B. et al.: European Polymer Journal 2019, 114, 57. https://doi.org/10.1016/j.eurpolymj.2019.02.030

[19] Monnier X., Delpouve N., Basson N. et al.: Polymer 2015, 73, 68 . https://doi.org/10.1016/j.polymer.2015.07.047

[20] Szustakiewicz K., Stępak B., Antończak A.J. et al.: Polymer Degradation and Stability 2018, 149, 152. https://doi.org/10.1016/j.polymdegradstab.2018.01.015

[21] Zhang J., Tashiro K., Tsuji H. et al.: Macromolecules 2008, 41, 1352. https://doi.org/10.1021/ma0706071

[22] Zhou S., Zheng X., Yu X.: Chemistry of Materials 2007, 19, 247. https://doi.org/10.1021/cm0619398

[23] Wang Y., Funari S.S., Mano J.F.: Macromolecular Chemistry and Physics 2006, 207, 1262. https://doi.org/10.1002/macp.200600114

[24] Androsch R., Schick C., Laura M. et al.: Macromolecular Chemistry and Physics 2014, 215, 1134. https://doi.org/10.1002/macp.201400126

Received 15 III 2020 